EXTENDED REPORT

\title{
Lack of radiological and clinical benefit over two years of low dose prednisolone for rheumatoid arthritis: results of a randomised controlled trial
}

\author{
H A Capell, R Madhok, J A Hunter, D Porter, E Morrison, J Larkin, E A Thomson, R Hampson, \\ F W Poon, on behalf of the WOSERACT* Group
}

Ann Rheum Dis 2004;63:797-803. doi: 10.1136/ard.2003.014050

See end of article for authors' affiliations

Correspondence to Dr H A Capell, Centre for Rheumatic Diseases, Glasgow Royal Infirmary, North Glasgow University NHS Trust, Castle St, Glasgow G40SF, UK Hilary.Capell@ northglasgow.scot.nhs.uk

Accepted 8 October 2003

\begin{abstract}
Background: Evidence for disease modifying activity of low dose corticosteroid treatment in rheumatoid arthritis is contradictory. Studies showing radiological benefit suggest that continued treatment is required to sustain the effect.

Objective: To evaluate the effect of low dose oral prednisolone in early rheumatoid arthritis on disease activity over two years.

Design: Double blind placebo controlled trial.

Methods: Patients with rheumatoid arthritis, duration $<3$ years $(n=167)$, were started on a disease modifying antirheumatic drug (DMARD; sulphasalazine) and allocated by stratified randomisation to prednisolone $7 \mathrm{mg} /$ day or placebo. Primary outcome measure was radiological damage, assessed by the modified Sharp method. Clinical benefit was a secondary outcome. A proactive approach to identifying and treating corticosteroid adverse events was adopted. Patients who discontinued sulphasalazine were offered an alternative DMARD.

Results: 90 of 257 patients eligible for the study refused to participate (more women than men). Of those enrolled, 84\% were seropositive for rheumatoid factor, median age 56 years, median disease duration 12 months, female to male ratio 1.8:1. Prednisolone was given to 84 patients; of these $73 \%$ continued prednisolone and $70 \%$ sulphasalazine at 2 years. Of the 83 patients on placebo, $80 \%$ continued placebo and $64 \%$ sulphasalazine at 2 years. There were no significant differences in radiological score or clinical and laboratory measures at 0 and 2 years.

Conclusions: Low dose prednisolone conferred no radiological or clinical benefit on patients maintained on a DMARD over two years. Low dose corticosteroids have no role in the routine management of rheumatoid arthritis treated with conventional disease modifying drugs.
\end{abstract}

$\mathrm{R}$ heumatoid arthritis is a chronic inflammatory disorder primarily of synovium which results in pain, stiffness, impaired function, bone erosion at the cartilagesynovium interface, and loss of cartilage. Radiological progression of disease is best documented in $x$ rays of the hands and feet and is manifested as loss of joint space and bone erosions in the periarticular areas. In the majority of patients erosions appear early in the disease and progress in a constant manner, in close association with the extent of the acute phase response. Current evidence advocates the early and sustained use of disease modifying anti-rheumatic drugs (DMARD), ${ }^{1}$ which not only control the inflammatory component of the disease but also reduce the rate of radiological progression.

Since their introduction in $1949,{ }^{2}$ the role of corticosteroids in rheumatoid arthritis has been controversial. Despite early evidence that they may alter disease progress, ${ }^{3}$ steroids fell from favour in the United Kingdom. More recent studies include a retrospective analysis of patients on intramuscular gold which showed that oral corticosteroids provided no radiological benefit, ${ }^{4}$ and a study from van Gestel et al, who reported similar results in a small prospective randomised double blind controlled study using oral steroids as a bridge with intramuscular gold. ${ }^{5}$ In established rheumatoid arthritis, a marginal radiological benefit in patients receiving a mean of $4.5 \mathrm{mg}$ of oral prednisolone in combination with a DMARD has been reported. ${ }^{6}$ In a randomised double blind controlled trial, the Arthritis Research Council (ARC) Low
Dose Corticosteroid Group compared $7.5 \mathrm{mg}$ of prednisolone with placebo and reported that radiological progression was reduced in prednisolone treated patients. ${ }^{7}$ In that study DMARD use was left to the discretion of the treating rheumatologist. The strength of the ARC study was that it was adequately powered, prospective, randomised, and double blind. However, the groups were not well matched at the outset, and DMARD use was suboptimal. On withdrawal of prednisolone, erosion and cartilage loss recurred. ${ }^{8}$

While one recent study of low dose oral corticosteroids without DMARD has shown a beneficial effect on clinical measures of disease activity and on radiological damage, ${ }^{9}$ using low dose oral corticosteroids without DMARD is not current rheumatological practice in most centres. The COBRA (Combinatietherapie Bij Reumatoide Artritis) study of high dose step down oral prednisolone with methotrexate and sulphasalazine showed radiological advantage over sulphasalazine alone but the study was not powered to detect differences in $x$ ray change. ${ }^{10}$ In addition high dose steroids are associated with greater toxicity.

The evidence base for low dose oral corticosteroids is thus contradictory and the value of using them in early

Abbreviations: ACR, American College of Rheumatology; ARC, Arthritis Research Council; COBRA, combinatietherapie bij reumatoide artritis study; DMARD, disease modifying antirheumatic drug; $H A Q$, health assessment score; WOSERACT, West of Scotland early rheumatoid arthritis corticosteroid therapy study 
rheumatoid arthritis is debated. ${ }^{11}{ }^{12}$ If the positive low dose studies can indeed be confirmed, and adverse events prevented or minimised, prednisolone offers a cheap effective treatment to prevent long term disability. The main concern is cumulative toxicity, notably accelerated bone loss, susceptibility to infection, and a tendency to premature atheromatous vascular disease. All of these are comorbidities that are a feature of rheumatoid arthritis itself. ${ }^{13-17}$

To justify exposing patients with rheumatoid arthritis to the risks of prolonged low dose oral corticosteroid treatment, it is therefore necessary to confirm radiological benefit in well matched groups in a controlled study, and demonstrate clinically significant risk-benefit advantage.

In this study we aimed to evaluate the effect of low dose oral prednisolone in addition to a DMARD (sulphasalazine) in early rheumatoid arthritis on radiological damage and clinical indices of disease activity over two years. We also documented possible corticosteroid toxicity at each visit and were proactive in the introduction of treatment to mitigate side effects.

\section{METHODS}

Four hospital based rheumatology units within Glasgow and four outside the city cooperated in the West of Scotland early rheumatoid arthritis corticosteroid therapy (WOSERACT) study.

\section{Patients}

Patients with rheumatoid arthritis, as defined by the American College of Rheumatology, ${ }^{18}$ between the ages of 18 and 75 years and with symptoms for less than three years, were included in the study if they had three of the following: $\geqslant$ six painful joints; $\geqslant$ three swollen joints; $\geqslant 20$ minutes early morning stiffness; erythrocyte sedimentation rate (ESR) $\geqslant 28 \mathrm{~mm}$ in the first hour; or $\mathrm{C}$ reactive protein $\geqslant 10 \mathrm{mg} / \mathrm{l}$. We excluded patients known to have peptic ulcer disease and not on gastro-protection with either an $\mathrm{H}_{2}$ antagonist, a proton pump inhibitor, or a prostaglandin analogue, or who had received DMARD treatment other than hydroxychloroquine in the previous four weeks. No patient was on hydroxychloroquine at time of initiation of the study.

\section{Intervention}

Patients were started on $500 \mathrm{mg} /$ day of sulphasalazine and the dose was increased weekly by $500 \mathrm{mg} /$ day to a target dose of $40 \mathrm{mg} / \mathrm{kg}$ unless toxicity limited increments. Sulphasalazine was monitored as advised by the British Society of Rheumatology. NSAID treatment was at the discretion of the individual physician, as was further DMARD use if sulphasalazine failed.

Randomisation to prednisolone $7 \mathrm{mg}$ daily or placebo was undertaken at the main study centre. Patients were stratified according to rheumatoid factor status, sex, age, and the presence or absence of erosions by a minimisation method. ${ }^{19}{ }^{20}$ Changes in the appearance of prednisolone and placebo occurred over the six years of the study because $5 \mathrm{mg}$ and $1 \mathrm{mg}$ tablets had to be sourced from various different suppliers during the study. Pyridoxine was the original placebo; in 1997 following a Committee of Safety Medicines directive about long term pyridoxine use, ${ }^{21}$ ascorbic acid tablets similar in appearance and size were substituted. Patients in both groups were alerted to the change in appearance of the drug but not to treatment allocation. The patients, clinicians, and nurse specialists were made aware of the difficulties but remained unaware of the drug allocation. The study coordinator (EAT) was aware of the allocation and coordinated supplies for the centres. The integrity of the study was thus maintained as both agents changed in appearance at times during the study. After two years, gradual withdrawal of steroid/placebo was undertaken over five months (reducing initially $7 \mathrm{mg}$ to $5 \mathrm{mg}$ then by $1 \mathrm{mg}$ every month).

\section{Measurements}

Baseline information collected included: age, disease duration (as defined from symptom onset rather than time of diagnosis), sex, rheumatoid factor status, initial presence of erosions, smoking habit, and Carstairs deprivation score. ${ }^{22}$ Clinical measures at baseline and every 12 months included pain score, physician and patient global assessment of activity (rated on $10 \mathrm{~cm}$ visual analogue scale), Ritchie articular index, ${ }^{23}$ and health assessment score (HAQ) ${ }^{24}$ with British modification. ${ }^{25}$ Laboratory measures included haemoglobin, ESR, and $\mathrm{C}$ reactive protein measured as clinically indicated and on an annual basis.

Standard postero-anterior $x$ rays of hands and feet were obtained at baseline and at one and two years. All radiographs were scored using the van der Heijde modification of the Sharp method. ${ }^{26}$ The maximum erosion score is 160 for the hands and 120 for the feet, and the maximum score for hand joint space narrowing is 120 and for the feet 48 . The maximum possible total score is 448. Two observers independently scored $x$ rays of the hands and feet for erosions and joint space narrowing. $\mathrm{JH}$, a rheumatologist, scored them in an entirely random order, and FWP, a radiologist, score them knowing the chronological sequence. ${ }^{27}$ Neither was aware of patient details or treatment allocations.

Measurements of prednisolone toxicity at each centre included: body mass index (BMI), blood pressure, random cholesterol, high density lipoprotein (HDL) cholesterol, and glucose. Patients from all but one centre had bone mineral density measured (using dual energy $x$ ray absorptiometry, DEXA). It was recognised that low dose steroids could lead to adverse effects. Therefore where baseline assessments of BMI, blood pressure, DEXA, lipids, or glucose were abnormal, or when these became abnormal in the course of the study, appropriate intervention was left to the discretion of the rheumatologist responsible for that patient. All concomitant treatment was also recorded.

\section{Statistical methods}

We calculated that 160 patients were required to have $90 \%$ power to detect a $50 \%$ reduction in progression of total joint erosions over two years with a significance of $p<0.05$. No interim analysis was carried out. The primary outcome measure was radiological change in the hands and feet (joint space narrowing and erosions). ${ }^{26}$ Secondary outcome measures included clinical and laboratory measures of benefit and frequency of toxicity. An intention to treat analysis was used. Total joint count (narrowing and erosions in hands and feet) in the active and placebo groups was compared using the Mann-Whitney U test. Clinical variables were analysed similarly and within-group changes were evaluated using Wilcoxon matched pairs signed ranks test. Strengths of associations were obtained by Spearman rank correlations.

\section{RESULTS}

Enrolment began in February 1996 and the last patient completed two years of follow up in May 2001. We recorded all eligible patients including those reluctant to participate (fig 1). In all, 257 patients were assessed for the study. Of these, 90 were excluded either because they did not want corticosteroid treatment, or did not meet entry criteria on closer assessment, or did not wish to participate for reasons unspecified. Figure 1 also shows the flow of all participants through each phase of the study.

Of the 167 patients started on sulphasalazine, 84 were randomised to prednisolone $7 \mathrm{mg}$ daily and 83 to matching 


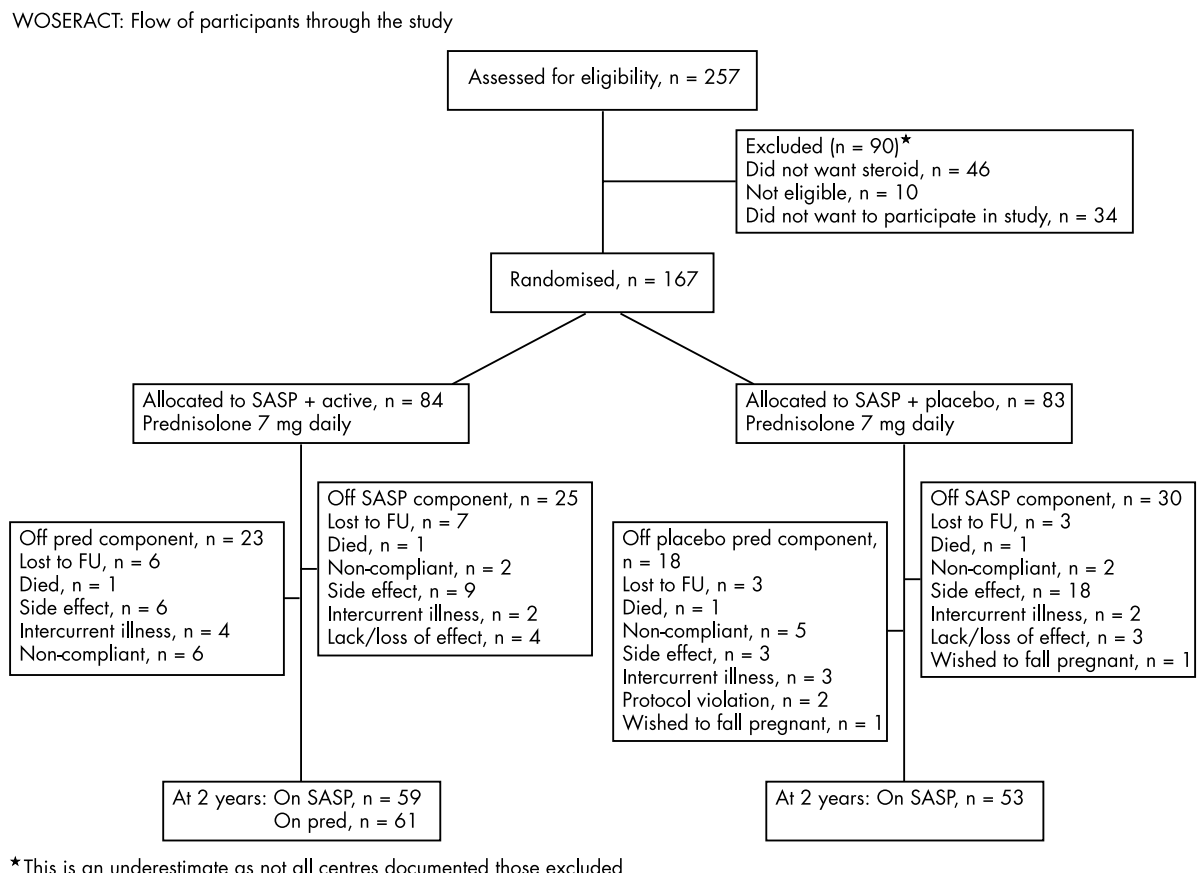

Figure 1 Flow of participants through the WOSERACT study. FU, follow up; pred, prednisolone; SASP, sulphasalazine

placebo. Table 1 shows the baseline demographic information and clinical and laboratory variables. The female to male ratio was 1.8:1. Patients in the prednisolone and placebo groups were equally distributed in Carstairs groupings, an index of deprivation. Only $10 \%$ of patients were from affluent areas, while $34 \%$ lived in the most deprived districts.

Intention to treat analysis at one year was possible in 77 individuals allocated to prednisolone and 74 to placebo. Seven in the prednisolone group and three on placebo were lost to follow up. One in the prednisolone group withdrew consent to continue in the study. Analysis at two years was possible in 70 prednisolone and 72 placebo patients. One patient died in each treatment group of causes unrelated to treatment. At two years, 25 patients from the prednisolone group were no longer on sulphasalazine and 23 were no longer taking prednisolone. In the placebo group 30 had stopped sulphasalazine and 18 were no longer on placebo.

\section{DMARD treatment}

Adverse events leading to withdrawal were as expected for sulphasalazine. Nausea and vomiting (active 3, placebo 7), rash $(2,3)$, mouth ulcers $(2,0)$, leucopenia $(1,3)$, dizziness $(1,0)$, or abnormal liver function tests $(0,3)$ led to withdrawal of treatment in prednisolone and placebo groups. At two years 57 patients were on sulphasalazine in the active group $(68 \%)$ and 54 in the placebo group (65\%). More side effects necessitated withdrawal of sulphasalazine (18/83 $(22 \%)$ in the placebo group $v 9 / 84$ (11\%) on prednisolone).

\begin{tabular}{|c|c|c|c|c|}
\hline Variable & $\begin{array}{l}\text { Entire sample } \\
(n=167)\end{array}$ & $\begin{array}{l}\text { Active drug } \\
(n=84)\end{array}$ & $\begin{array}{l}\text { Placebo } \\
(n=83)\end{array}$ & $\begin{array}{l}\text { Mann-Whitney } \\
\text { U test }\end{array}$ \\
\hline Age (years) & $\begin{array}{l}56 \\
\text { (21 to } 72 \text { ) }\end{array}$ & $\begin{array}{l}55 \\
(25 \text { to } 76)\end{array}$ & $\begin{array}{l}56 \\
(21 \text { to } 76)\end{array}$ & NS \\
\hline Disease duration (months) & $\begin{array}{l}12 \\
(2 \text { to } 84)\end{array}$ & $\begin{array}{l}12 \\
(3 \text { to } 36)\end{array}$ & $\begin{array}{l}12 \\
(2 \text { to } 84)\end{array}$ & NS \\
\hline RF positivity & $84 \%$ & $84 \%$ & $85 \%$ & \\
\hline Per cent erosive & $51 \%$ & $51 \%$ & $52 \%$ & \\
\hline Ratio M:F (n:n) & $59: 108$ & $29: 55$ & $30: 53$ & \\
\hline Per cent smokers & $46 \%$ & $45 \%$ & $47 \%$ & \\
\hline Swollen joints & $\begin{array}{l}10 \\
(0 \text { to } 30)\end{array}$ & $\begin{array}{l}9 \\
(0 \text { to } 30)\end{array}$ & $\begin{array}{l}12 \\
(0 \text { to } 30)\end{array}$ & NS \\
\hline Early morning stiffness & $\begin{array}{l}60 \\
(0 \text { to } 720)\end{array}$ & $\begin{array}{l}90 \\
(5 \text { to } 720)\end{array}$ & $\begin{array}{l}60 \\
(0 \text { to } 720)\end{array}$ & NS \\
\hline Pain score & $\begin{array}{l}55 \\
(0 \text { to } 100)\end{array}$ & $\begin{array}{l}54 \\
(3 \text { to } 100)\end{array}$ & $\begin{array}{l}56 \\
(0 \text { to } 100)\end{array}$ & NS \\
\hline Articular index & $\begin{array}{l}14 \\
(2 \text { to } 56)\end{array}$ & $\begin{array}{l}14 \\
\text { (3 to } 47)\end{array}$ & $\begin{array}{l}17 \\
(2 \text { to } 56)\end{array}$ & NS \\
\hline $\operatorname{ESR}(\mathrm{mm} / \mathrm{h})$ & $\begin{array}{l}38 \\
(2 \text { to } 140)\end{array}$ & $\begin{array}{l}34 \\
\text { (2 to 124) }\end{array}$ & $\begin{array}{l}40 \\
\text { (3 to } 140)\end{array}$ & NS \\
\hline $\mathrm{C}$ reactive protein $(\mathrm{mg} / \mathrm{l})$ & $\begin{array}{l}21 \\
\text { (3 to } 338 \text { ) }\end{array}$ & $\begin{array}{l}17 \\
\text { (5 to } 338)\end{array}$ & $\begin{array}{l}25 \\
\text { (3 to } 234 \text { ) }\end{array}$ & NS \\
\hline $\mathrm{HAQ}$ & $\begin{array}{l}1.75 \\
(0 \text { to } 3.0)\end{array}$ & $\begin{array}{l}1.75 \\
(0 \text { to } 3.0)\end{array}$ & $\begin{array}{l}1.625 \\
(0 \text { to } 3.0)\end{array}$ & NS \\
\hline
\end{tabular}


Seventeen patients on prednisolone and 23 placebo treated patients discontinued sulphasalazine and were on an alternative DMARD. Eight of the placebo treated patients and 11 of the active group were no longer on a DMARD at two years. Methotrexate, intramuscular gold, and hydroxychloroquine were the commonly used alternative DMARDs after sulphasalazine withdrawal.

\section{Steroid/placebo treatment}

Seventy three per cent remained on prednisolone and $80 \%$ on the placebo at two years. One patient withdrew consent after starting in the study. A further 11 were lost to follow up. Withdrawals from the steroid or placebo for side effects considered attributable to that treatment were rare-six in the prednisolone cohort (facial swelling 1, weight gain 3, nausea 1, gastrointestinal bleed 1) and two in the placebo cohort (nausea 1, diarrhoea 1).

\section{Radiology}

Radiology was available in 64/83 (77\%) on active prednisolone and 66/84 (79\%) on placebo. The correlation coefficient between the total score for all $x$ rays read in random order and those read in chronological sequence was $r=0.8$ $(p=0.01)$. Twenty three patients had no erosions at the start of the study; eight had developed erosions after two years; two were on prednisolone and six on placebo. Of patients with erosions at onset, 59\% and 61\% showed progression in the placebo and prednisolone groups, respectively. Comparison of initial and two year total scores in both placebo and prednisolone groups showed significant deterioration (table 2). There was no difference between the groups in total scores or in any other radiological variable examined individually for both random ( $\mathrm{JH})$ and chronological (FWP) scoring (table 2, fig 2). The results were similar when reading hands and feet separately and when scoring erosions/narrowing separately (data not shown).

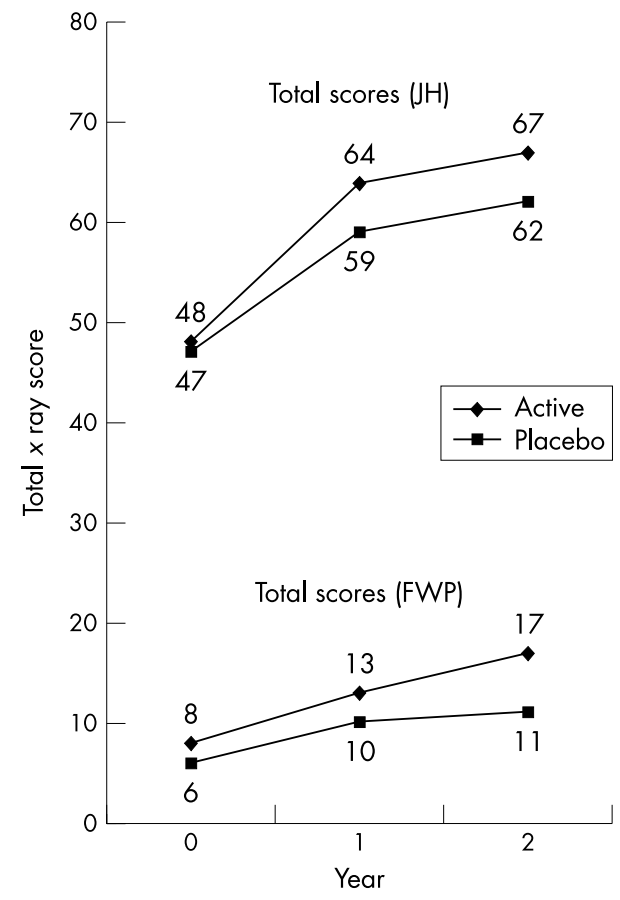

Figure 2 Changes in total $x$ ray score over two years. FWP, F W Poon (radiologist), chronological scoring; JH, J A Hunter (rheumatologist), random scoring.

\section{Clinical efficacy}

There was an improvement in clinical measures and in a "modified ACR" (20\% improvement in Ritchie articular index and in four of five variables (ESR, pain score, physician global, patient global, $\mathrm{HAQ}^{24}$ ) in both groups. At one year, $53 \%$ of prednisolone treated patients showed a "modified" $20 \%$ response, compared with $39 \%$ on placebo $(p=0.07)$. At two years, $41 \%$ on prednisolone and $43 \%$ on placebo showed a "modified" ACR 20\% response. The group receiving oral prednisolone had a lower ESR at year $\mathrm{l}(\mathrm{p}=0.05)$ but not at year 2 . There were no other significant differences between the groups at years 1 or 2 in other clinical or laboratory measures or in functional ability. The results are detailed in table 3.

\section{Toxicity}

Toxicity data relating to blood pressure, weight, BMI, and DEXA are shown in table 4.

Antihypertensive and anti-bone-resorptive treatment was more often used in the prednisolone group (table 5). Despite this there was a trend towards higher diastolic blood pressure in the active group at year 1 (table 4). There was also a significant weight gain in the active group in years 1 and 2 , with an associated increase in BMI. The placebo group did not show an increase in weight at year 1 but there was a borderline change at year 2 . There was no significant difference in the lipids at outset or at 2 years in those patients in whom it was measured (total cholesterol/HDL cholesterol).

The percentage change in femoral neck and L2-L4 DEXA scores in the active prednisolone and placebo groups were compared using the Mann-Whitney $U$ test. There was no significant difference between the two groups for either score $(\mathrm{p}=0.315$ and 0.215 , respectively).

\section{Concomitant treatment}

Concomitant treatment is shown in table 5. Use of nonsteroidal anti-inflammatory drugs (NSAID) decreased in both groups to a similar extent, in keeping with a DMARD response. Low dose aspirin and treatment for ischaemic heart disease remained similar, whereas the use of antihypertensive agents increased in both groups, as did prescription of lipid lowering agents. The use of any treatment for osteoporosis also increased in both groups.

\section{Additional intramuscular or intra-articular corticosteroids}

Additional intramuscular or intra-articular steroids were given to $43 \%$ of the placebo group and $49 \%$ of the active group over the course of the study (mean dose $55 \mathrm{mg}$ of triamcinolone acetate and $52 \mathrm{mg}$ in placebo and active groups, respectively).

\section{DISCUSSION}

The most striking finding in this study was that there was no demonstrable benefit of low dose prednisolone on progression of erosions, a marker of bone damage, or on reducing the extent of joint space narrowing, an indicator of cartilage loss, as noted on $x$ rays of hands and feet. This was true when $x$ rays were read in chronological or totally random order. Low dose prednisolone provided marginal clinical benefit in early rheumatoid arthritis but this was not sustained beyond 12 months. This is similar to the results of other studies and suggests that when used with early DMARD treatment oral prednisolone provides no additional sustained advantage in symptoms or in measures of the inflammatory component of the disease.

Of the previous studies that have shown radiological benefit from low dose oral corticosteroid therapy, the largest 
Table 2 Radiological data (van der Heijde modification of Sharp method)

\begin{tabular}{|c|c|c|c|c|}
\hline & 0 & 1 & 2 & p Value (Wilcoxon 0-2) \\
\hline \multicolumn{5}{|c|}{ (A) Total scores (FWP) (narrowing+erosions hands and feet), chronological reading of films } \\
\hline Active prednisolone & $\begin{array}{l}8 \\
(0 \text { to } 80)\end{array}$ & $\begin{array}{l}13 \\
(0 \text { to } 82)\end{array}$ & $\begin{array}{l}17 \\
(0 \text { to } 91)\end{array}$ & $p<0.001$ \\
\hline Placebo prednisolone & $\begin{array}{l}6 \\
(0 \text { to } 80)\end{array}$ & $\begin{array}{l}10 \\
(0 \text { to } 108)\end{array}$ & $\begin{array}{l}11 \\
\text { (0 to } 143 \text { ) }\end{array}$ & $p<0.001$ \\
\hline Mann-Whitney & 0.630 & 0.815 & 0.722 & \\
\hline \multicolumn{5}{|c|}{ (B) Total scores (JH) (narrowingterosions hands and feet), random reading of films } \\
\hline Active prednisolone & $\begin{array}{l}48 \\
\text { (8 to } 159 \text { ) }\end{array}$ & $\begin{array}{l}64 \\
\text { (9 to } 174 \text { ) }\end{array}$ & $\begin{array}{l}67 \\
\text { (12 to } 173)\end{array}$ & $p<0.001$ \\
\hline Placebo prednisolone & $\begin{array}{l}47 \\
(11 \text { to } 135)\end{array}$ & $\begin{array}{l}59 \\
(8 \text { to } 213 \text { ) }\end{array}$ & $\begin{array}{l}62 \\
(10 \text { to } 283 \text { ) }\end{array}$ & $p<0.001$ \\
\hline Mann-Whitney & 0.834 & 0.564 & 0.778 & \\
\hline
\end{tabular}

and most rigorous is the ARC multicentre study. Scrutiny of factors that might explain the discrepancy in results reveals that conventional DMARD use was more consistent in WOSERACT than in the ARC study. All the patients in WOSERACT received sulphasalazine initially (and a subsequent DMARD in $14 \%$ if sulphasalazine was not tolerated), whereas only $66 \%$ of patients in the ARC study received a DMARD and there was no consistency across the two treatment allocations in that study. It is possible-although there is no evidence base-that sulphasalazine does not synergise with corticosteroid treatment. The female to male ratio, age distribution, disease duration, clinical disease severity, and rheumatoid factor positivity were similar (acute phase response and rheumatoid factor status ${ }^{28} 29$ have been shown to have an influence on radiological progression), and the proportion of patients in whom $x$ rays were available was also similar ( $83 \%$ in the ARC study and $78 \%$ in ours). The studies differed in that the proportion of patients with erosive disease was different in WOSERACT from the ARC study. Significantly more patients in our study had erosive disease (71\% had erosive disease of hands in this study, compared with $31 \%$ in the ARC study, $p=0.03$ by $\chi^{2}$; the data were similar at the end of year 1). However, in the ARC study more patients in the placebo group compared with the prednisolone group had erosive disease at the outset, whereas the WOSERACT groups were well matched, probably as a result of randomisation with stratification using a minimisation technique.

The natural history of non-erosive rheumatoid disease is well documented-few patients without erosive disease at the time of diagnosis progress. This contrasts with those who had erosive changes at the start of the study; in these the progression was the result of damage increasing in the eroded joints over time, rather than more non-eroded joints developing erosions. It is therefore possible that the difference in results partly reflects the populations studied, with a bias towards erosive disease in the WOSERACT cohort. Long term more severe disability is more likely to develop in such patients.

We used a different method to measure $x$ ray damage in WOSERACT than was used in the ARC study-namely, the van der Heidje modification of the Sharp method rather than the Larsen score. ${ }^{30} \mathrm{JH}$, using the random method, had higher scores than FWP, who used the chronological method. It was nevertheless reassuring that the change in $x$ ray score was consistent between the two readers. The modified Sharp method is the preferred measurement in evaluating change over time, has a larger range and a greater sensitivity to change, and takes into account changes in the feet, one of the first sites to be affected in rheumatoid arthritis. It has also been the more common method used in recent studies of DMARD in rheumatoid arthritis. ${ }^{31}$ Furthermore, to be $95 \%$ confident to detect true change by the Larsen score an increase in score of 8 units is required over one year; the mean increase in the ARC study was 5.4 units over two years.

An alternative explanation of the divergent results of the two studies may be a genetic difference in the populations studied. We have previously observed that there is an overrepresentation of HLA-DR4 in the west of Scotland ${ }^{32}$; this allele is associated with more severe clinical and radiological disease. Differences in corticosteroid metabolism or in the frequency of the CRF gene polymorphisms-which have been shown in one rheumatoid arthritis cohort-may be another explanation that requires further evaluation.

The male to female ratio in this study is unlike many other DMARD studies in that comparatively greater numbers of men than women were willing to accept the risk of steroids. Men comprised 35\% of our group, which is considerably more

Table 3 Clinical and laboratory change in the two groups

\begin{tabular}{|c|c|c|c|c|c|c|}
\hline \multirow[b]{2}{*}{ Year } & \multicolumn{3}{|c|}{ Prednisolone $n=84$} & \multicolumn{3}{|l|}{ Placebo $n=83$} \\
\hline & 0 & 1 & 2 & 0 & 1 & 2 \\
\hline ESR $(\mathrm{mm} / \mathrm{h})$ & 34 (2 to 124$)$ & $12^{*}(1$ to 82$)$ & $14(1$ to 102$)$ & $40(3$ to 140$)$ & $18^{*}(1$ to 120$)$ & $20(1$ to 112$)$ \\
\hline $\mathrm{C}$ reactive protein $(\mathrm{mg} / \mathrm{l})$ & 18 (5 to 238$)$ & $10(4$ to 114$)$ & $10(3$ to 120$)$ & 25 (3 to 234$)$ & $10(1$ to 120$)$ & $10(1$ to 98$)$ \\
\hline Pain score & $54(3$ to 100$)$ & $42(0$ to 98$)$ & $47(0$ to 100$)$ & $56(0$ to 100$)$ & $50(0$ to 100$)$ & $46(0$ to 100$)$ \\
\hline Physician global & $2(0$ to 4$)$ & $1(0$ to 4$)$ & $2(0$ to 4$)$ & $2(0$ to 4$)$ & $1(0$ to 4$)$ & $1(0$ to 3$)$ \\
\hline Patient global & $2(0$ to 4$)$ & $1(0$ to 4$)$ & $2(0$ to 4$)$ & $2(0$ to 4$)$ & $2(0$ to 4$)$ & $2(0$ to 4$)$ \\
\hline Ritchie articular index & $14(3$ to 47$)$ & $7(0$ to 52$)$ & $8(0$ to 60$)$ & $17(2$ to 56$)$ & $8(0$ to 66$)$ & $7(0$ to 73$)$ \\
\hline $\mathrm{HAQ}$ & $1.75(0$ to 3$)$ & $1.38(0$ to 2.9$)$ & $1.38(0$ to 3$)$ & $1.63(0$ to 3$)$ & $1.5(0$ to 3$)$ & $1.5(0$ to 2.75$)$ \\
\hline
\end{tabular}

Values are median (range).

*Mann-Whitney $U$ test, $p=0.05 v$ prednisolone group. All other between-group comparisons non-significant.

$\mathrm{HAQ}$, heath assessment questionnaire. 
Table 4 Toxicity data relating to blood pressure, weight, body mass index, and bone mineral density over two years

\begin{tabular}{|c|c|c|c|c|c|c|c|c|c|}
\hline \multirow[b]{2}{*}{ Variable } & \multicolumn{4}{|l|}{ Active } & \multicolumn{4}{|l|}{ Placebo } & \multirow[b]{2}{*}{ Mann-Whitney $U$ test } \\
\hline & 0 & 1 & 2 & $\begin{array}{l}\text { Wilcoxon } \\
(0-1 / 0-2)\end{array}$ & 0 & 1 & 2 & $\begin{array}{l}\text { Wilcoxon } \\
(0-1 / 0-2)\end{array}$ & \\
\hline Systolic BP (mm Hg) & 140 & 140 & 140 & $0.424 / 0.551$ & 135 & 140 & 130 & $0.038 / 0.703$ & $\begin{array}{l}0.503 \text {, year } 0 \\
0.471 \text {, year } 1 \\
0.620 \text {, year } 2\end{array}$ \\
\hline Diastolic BP (mm Hg) & 80 & 82 & 80 & $0.057 / 0.818$ & 80 & 80 & 80 & $0.070 / 0.288$ & $\begin{array}{l}0.106 \text {, year } 0 \\
0.055 \text {, year } 1 \\
0.424 \text {, year } 2\end{array}$ \\
\hline Weight (kg) & 68 & 71 & 72 & $0.000 / 0.000$ & 69 & 70 & 72 & $0.162 / 0.031$ & $\begin{array}{l}0.551 \text {, year } 0 \\
0.218 \text {, year } 1 \\
0.255 \text {, year } 2\end{array}$ \\
\hline BMI $\left(\mathrm{kg} / \mathrm{m}^{2}\right)$ & 24.9 & 25.7 & 26.2 & $0.000 / 0.000$ & 25.1 & 25.7 & 26.0 & $0.119 / 0.035$ & $\begin{array}{l}0.950, \text { year } 0 \\
0.396, \text { year } 1 \\
0.355 \text {, year } 2\end{array}$ \\
\hline Median weight gain & & & $4 \mathrm{~kg}$ & & & & $3 \mathrm{~kg}$ & & \\
\hline $\begin{array}{l}\text { Bone mineral density } \\
\text { Femoral neck } \\
\text { Lumbar spine } \\
\text { L2-L4 }\end{array}$ & 0.8995 & - & 0.8810 & & 0.9270 & - & $\begin{array}{l}0.9110 \\
1.280\end{array}$ & & $\begin{array}{l}0.308, \text { year } 0 \\
0.228 \text {, year } 2 \\
0.193 \text {, year } 0\end{array}$ \\
\hline
\end{tabular}

Table 5 Concomitant treatment

\begin{tabular}{|c|c|c|c|c|}
\hline & Placebo $0(n=83)$ & Placebo $2(n=75)$ & Active $0(n=84)$ & Active $2(n=71)$ \\
\hline NSAID & $71(86)$ & $53(71)$ & $70(83)$ & $44(62)$ \\
\hline Aspirin & $8(10)$ & $7(9)$ & $6(7)$ & $4(6)$ \\
\hline Antihypertensive agents & $12(14)$ & $16(21)$ & $10(12)$ & $13(18)$ \\
\hline Lipid lowering agent & $2(2)$ & $4(5)$ & $0(0)$ & $1(2)$ \\
\hline IHD treatment & $6(2)$ & $6(8)$ & $2(2)$ & $2(3)$ \\
\hline HRT & $4(5)$ & $5(7)$ & $11(13)$ & 12 (17) \\
\hline Bisphosphonates & $1(1)$ & $4(5)$ & $2(2)$ & $9(13)$ \\
\hline Any OP treatment & $5(6)$ & $9(12)$ & $13(15)$ & $21(30)$ \\
\hline \multicolumn{5}{|c|}{$\begin{array}{l}\text { Values are } n(\%) \text {. } \\
\text { HRT, hormone replacement therapy; IHD, ischaemic heart disease; NSAID, non-steroidal anti-inflammatory drug } \\
\text { OP, osteoporosis. }\end{array}$} \\
\hline
\end{tabular}

than in the other DMARD studies but similar to that in the ARC and COBRA studies. ${ }^{70}$ It may be that women are more concerned about the perceived cosmetic problems associated with corticosteroids, and were therefore more likely to refuse to take part.

It is noteworthy that the prescription of antihypertensive agents and osteoporosis treatments increased in both groups. Weight gain occurred in the prednisolone group at years 1 and 2 . The borderline change in the placebo group might reflect improvement in disease activity. These trends probably in part reflect monitoring of risk factors. While observed toxicity from corticosteroids in terms of hypertension, weight gain, and osteoporosis could be reduced by active assessment and prompt intervention, there is no room for complacency. Such interventions are expensive and long term sequelae cannot all be prevented, as has been highlighted in observational cohorts.

\section{Conclusions}

Our study failed to demonstrate any radiological or clinical benefit over two years from low dose prednisolone in patients with rheumatoid arthritis. It is possible that the standardised DMARD (sulphasalazine) and extensive use of alternative DMARDs in patients who failed on sulphasalazine conferred benefits in this study which outweighed any prednisolone effect. These results suggest that the routine use of low dose prednisolone provides no benefit in patients with rheumatoid arthritis receiving DMARD.

\section{ACKNOWLEDGEMENTS}

We are grateful to Ann Tierney for typing the manuscript, Dorothy McKnight for computing assistance, and Drs Alistair Forrester and Denis Pitkeathley for reading some $x$ rays. Metrology assistance was provided by Sylvia Armstrong, Fiona McDonald, Darryl McGhee, Fiona McGhee, Elizabeth McIvor, Anne Paterson, and Anne Stirling. Dr A Kelman, University of Glasgow, assisted with the statistical method of minimisation.

The Centre for Rheumatic Diseases receives an integrated clinical arthritis centre grant from the Arthritis Research Council (UK). We are also grateful to The Sir Hugh Fraser Foundation (Glasgow) for financial support to purchase prednisolone and placebo tablets.

\section{Authors' affiliations}

H A Capell, R Madhok, R Hampson, Centre for Rheumatic Diseases, Glasgow Royal Infirmary, Glasgow, UK

F W Poon, Department of Radiology, Glasgow Royal Infirmary

J A Hunter, D Porter, E A Thomson, Rheumatology Department, Gartnavel General Hospital, Glasgow

E Morrison, Rheumatology Department, Southern General Hospital, Glasgow

J Larkin, Rheumatology Department, Victoria Infirmary, Glasgow

*West of Scotland Early Rheumatoid Arthritis Corticosteroid Trial 


\section{APPENDIX}

\section{Responsibilities}

Study design: Dr H A Capell, Dr R Madhok, Dr J A Hunter, Dr D Porter, and Dr E Morrison.

Study co-ordinator: E A Thomson

Randomisation: A Tierney

$X$ Ray scoring: Dr J A Hunter, Dr F W Poon

Data collection: Rosie Hampson

Data analysis: Dr H A Capell, Dr D Porter, and Dr R Madhok Manuscript preparation: Dr H A Capell, Rosie Hampson, Dr J Larkin, and Dr R Madhok

Patient recruitment: Dr Maciej Brzeski (Falkirk and District General Hospital); Dr Hilary A Capell, Dr Max Field, Professor Iain McInnes, Dr Rajan Madhok, Professor Roger Sturrock (Glasgow Royal Infirmary); Dr Susan Fraser and Dr Elaine Morrison (Southern General Hospital, Glasgow); Dr Paul McGill (Stobhill Hospital, Glasgow); Dr Elizabeth Murphy (Law Hospital, Lanarkshire); Dr Malcolm Steven (Raigmore Hospital, Inverness); Dr Asad Zoma (Stonehouse Hospital, Lanarkshire).

\section{REFERENCES}

1 Scottish Intercollegiate Guidelines Network. Management of early rheumatoid arthritis. Edinburgh: SIGN Executive, Royal College of Physicians of Edinburgh, No 48, December 2000.

2 Hench PS, Kendall EC, Slocumb CH, Polley HF. The effect of a hormone of the adrenal cortex (17-hydroxy-11-dehydrocortisone: Compound E) and of pituitary adrenocorticotrophic hormone on rheumatoid arthritis. Preliminary report. Prof Staff Meet Mayo Clin 1949;24:181-97.

3 Joint Committee of the Medical Research Council and Nuffield Foundation. A comparison of prednisolone with aspirin or other analgesics in the treatment of rheumatoid arthritis. Ann Rheum Dis 1959:18:173-87.

4 Corkhill M, Kirkham BW, Chikanza IC, Gibson T, Panayi GS. Intramuscular depot methylprednisolone induction of chrysotherapy in rheumatoid arthritis: a randomised clinical trial. Br J Rheumatol 1990;29:274-9.

5 van Gestel AM, Laan RFJM, Haagsma CJ, van de Putte LBA, van Riel PLVM Oral steroids as bridge therapy in rheumatoid arthritis patients starting with parenteral gold. A randomized double-blind placebo-controlled trial. Br J Rheumatol 1995;34:347-51.

6 Hansen M, Podenphant J, Florescu A, Stoltenberg M, Borch A, Kluger E, et al. A randomised trial of differentiated prednisolone treatment in active rheumatoid arthritis. Clinical benefits and skeletal side-effects. Ann Rheum Dis 1999:58:713-18.

7 Kirwan JR for the Arthritis and Rheumatism Council low-dose glucocorticoid study group. The effect of glucocorticoids on joint destruction in rheumatoid arthritis. N Engl J Med 1995;333:142-6.

8 Hickling P, Jacoby RK, Kirwan JR. Joint destruction after glucocorticoids are withdrawn in early RA. Arthritis and Rheumatism Council low dose glucocorticoid study group. Br J Rheumatol 1998;37:930-6.

9 Van Everdingen AA, Jacobs JWG, Siewertsz van Reesema DR, Bijlsma JWJ. Low-dose prednisolone therapy for patients with early active rheumatoid arthritis: clinical efficacy, disease-modifying properties, and side-effects: a randomised, double-blind, placebo-controlled clinical trial. Ann Intern Med 2002; 136: 1-12.

10 Boers M, Verhoeven AC, Markusse HM, van de Laar MAFJ, Westhovens R, van Denderen JC, et al. Randomised comparison of combined step-down prednisolone, methotrexate and sulphasalazine with sulphasalazine alone in early rheumatoid arthritis. Lancet 1997;350:309-18.

11 Boers M. The case for corticosteroids in the treatment of early rheumatoid arthritis. Rheumatology 1999:38:95-7.

12 Morrison E, Capell HA. Corticosteroids in rheumatoid arthritis - the case against. Rheumatology 1999;38:97-100.

13 de Niijs RNJ, Jacobs JWG, Biilsma JWJ, Lems WF, Laan RFJM, Houben HHM, et al. Prevalence of vertebral deformities and symptomatic vertebral fractures in corticosteroid treated patients with rheumatoid arthritis. Rheumatology 2001;40:1375-83.

14 Gudbjornsson B, Juliusson UI, Gudjonsson FV. Prevalence of long term steroid treatment and the frequency of decision making to prevent steroid induced osteoporosis in daily clinical practice. Ann Rheum Dis 2002;61:32-6.

15 Saag KG. Low-dose corticosteroid therapy in rheumatoid arthritis: balancing the evidence. Am J Med 1997;103:31-9S.

16 Saag KG. Resolved: low-dose glucocorticoids are neither safe nor effective for the long-term treatment of rheumatoid arthritis. Arthritis Care Res 2001;45:468-71.

17 Wolfe F, Mitchell DM, Sibley JT, Fries JF, Bloch DA, Williams CA, et al. The mortality of rheumatoid arthritis. Arthritis Rheum 1994;37:481-94.

18 Arnett FC, Edworthy SM, Bloch DA, McShare DJ, Fries JF, Cooper NS, et al. The American Rheumatism Association 1987: Revised criteria for the classification of rheumatoid arthritis. Arthritis Rheum 1988;31:315-24.

19 Taves DR. Minimization: a new method of assigning patients to treatment and control groups. Clin Pharmacol Ther 1974;15:443-53.

20 Treasure T, MacRae KD. Minimisation: the platinum standard for trials? Randomisation doesn't guarantee similarity of groups; minimisation does [Editorial]. BMJ 1998;317:362-3.

21 Department of Health. Committee on Toxicity of Chemicals in Food, Consumer Products and the Environment. Statement on vitamin B6 (pyridoxine) toxicity. London: Department of Health, 1997.

22 Carstairs V, Morris R. Deprivation and health in Scotland. Aberdeen Aberdeen University Press, 1991.

23 Ritchie DM, Boyle JA, Mclnnes JM, Jasani MK, Dalakos TG, Grieveson P, et al. Clinical studies with an articular index for the assessment of joint tenderness in patients with rheumatoid arthritis. Q J Med 1968;147:393-406.

24 Fries JF, Spitz PW, Young DY. The dimensions of health outcomes: the Health Assessment Questionnaire, disability and pain scales. J Rheumatol 1982;9:789-93.

25 Kirwan JR, Reeback JS. Standford health assessment questionnaire modified to assess disability in British patients with rheumatoid arthritis. $\mathrm{Br} J$ Rheumatol 1986;25:206-9.

26 van der Heijde DMFM. Plain x-rays in rheumatoid arthritis: overview of scoring methods, their reliability and applicability. Baillieres Clin Rheumatol 1996; 10:435-53

27 Bruynesteyn K, van der Heijde D, Boers M, Saudan A, Peloso P, Paulus H, et al. Reading films with or without known sequence: does it influence the accuracy to detect clinically important changes in the individual [abstract]. San Francisco: ACR 65th Annual Scientific Meeting, November, 2001.

28 Jansen LMA, van der Horst-Bruinsma IE, van Schaardenburg D, Bezemer PD, Dijkmans BAC. Predictors of radiographic joint damage in patients with early rheumatoid arthritis. Ann Rheum Dis 2001:60:924-7.

29 Bukhari M, Lunt $M$, Harrison BJ, Scott DGI, Symmons DPM, Silman AJ. Rheumatoid factor is the major predictor if increasing severity of radiographic erosions in rheumatoid arthritis. Arthritis Rheum 2002;46:906-12.

30 Larsen A, Dale K, Eek M. Radiographic evaluation of rheumatoid arthritis and related conditions by standard reference films. Acta Radiol Diagn 1977; 18:481-91.

31 Smolen JS, Kalden JR, Scott DL, Rozman B, Kvien TK, Larsen A, et al. Efficacy and safety of leflunomide compared with placebo and sulphasalazine in active rheumatoid arthritis: a double-blind, randomised, multicentre trial. Lancet 1999;353:259-66

32 Crilly A, Maiden N, Capell HA, Madhok R. Genotyping for disease associated HLA DR $\beta 1$ alleles and the need for early joint surgery in rheumatoid arthritis: a quantitative evaluation. Ann Rheum Dis 1999;58:114-17. 